of the summer's gardens and cover the prizes. The merchants of the town will ordinarily help by contributions of cash or kind. In the autumn an exhibit of garden products and public conferring of prizes can be combined into an interesting event.

\section{OTHER CIVIC VENTURES}

The garden committee can undertake, with the co-operation of the agricultural college, the improvement of the school grounds and plots around the public buildings if they are not already cared for by a town department. In fact there are many activities that will suggest themselves to the workers of the town as they go about looking for new fields to conquer. After a single season of gardens a town might well embark the following spring on a general clean-up preparatory to the garden activities of the summer. Some of the prizes awarded in the autumn may have been bulbs, which will add materially to the desire to clean up in the spring.

A town which has aroused the interest of everybody in gardens and es- tablished contact between its residents might then venture on a park and playground campaign with some assurance of success. The street-tree program should have brought the overhead wire evil to the front and possibly banished the wires to the alleys or back fence lines if the town cannot afford underground conduits. The treatment of streets in paving, parking, sidewalks and shade adapted to the uses of the street might well become in due time the subject of intelligent interest and so be followed by actual action.

Indeed, starting from an active garden committee and a town-wide participation in garden contests, all the more intricate problems of town planning, treatment and arrangement of streets, protection of residence zones, grouping and treatment of public buildings, treatment and route of main highways connecting with other towns, all of which require expert advice and substantial expense, might be achieved through the understanding and sympathy of all the people, a method based on sound democratic principle and applied in a way to develop habits of human co-operation.

\title{
HOW WE RUIN OUR GOVERNORS
}

\author{
BY ALFRED E. SMITH \\ Former Governor of New York
}

\begin{abstract}
"How long would any great corporation live if the man directing its affairs was compelled to spend 75 per cent of his time doing clerical work?" :: :: $\quad$ :: $\quad$ :: $\quad$ :: $\quad$ :: $\quad$ :: $\quad$ :: $\quad$ ::
\end{abstract}

How long would any great corporation live if the man directing its affairs was compelled to spend 75 per cent of his time doing clerical work, signing papers, listening to reports that might well be directed to a competent subordinate? Can you imagine Judge Gary of the Steel Trust, signing three copies of every lease that that corporation makes?
Can you imagine him reading over the contract for the removal of ashes from one of the plants? Can you imagine him signing hundreds and hundreds of papers that might well be signed by the attorney of the corporation or by a vice-president or some equally responsible individual?

Theoretically the governor is the 
head of the government. He is supposed to plan the broad administrative policy. People think that he deals with large affairs. As a matter of fact his energy is consumed by trivial details of a clerical or subordinate nature. There is little time and strength left for the high functions of his office. In addition to the reorganization of administrative departments to give him easy control and supervision over executive affairs, the governor must be relieved from scores of petty duties which demand his attention at serious detriment to his work for the people.

The most annoying duty that is placed upon the governor is his chairmanship of the trustees of public buildings. The capitol and agricultural hall in Albany are directly under the control of the trustees of public buildings, and the law contains a provision that all leases made between the state and the various landlords must be executed by the trustees of public buildings.

The trustees consist of the governor, the lieutenant-governor and the speaker of the assembly. It has been the fact for years that these three men come from widely different parts of the state. For the most trivial things the governor must call these men, after the adjournment of the legislature, from their homes to attend meetings for routine business.

The superintendent of the capitol should have some of the power now reposing in the trustees. He should be empowered to dispose of useless furniture and fittings. As the law now stands he cannot dispose of a broken desk or a broken chair (I had to confer over some desks worth $\$ 1.25$ each) without the consent of the trustees of public buildings. They have to award all contracts, and before the contract to take the ashes out of the power house can be renewed the trustees must meet and pass upon that solemn proposition.

The state makes hundreds of leases in various cities for branches of the different state departments. Even for the small gas testing station required by the public service commission, the rental of which may be only twenty dollars a month, the governor and other trustees must sign three copies of each lease. Before part payments can be made for contracts for repairs to the capitol the trustees must approve, although the determination of the matter is naturally in control of the state architect.

\section{JANITOR DUTY}

If a room is to be painted in the capitol or a new strip of carpet is to be laid, there must be a meeting of the trustees, and the work cannot progress until the governor lays aside his other duties and takes up for consideration the question of a few pots of paint.

The superintendent of buildings is so limited in his authority that he is really the janitor of the building, and seldom makes any important move without seeking the advise of the governor or his secretary, all of which takes considerable time. His powers should be amply extended. He should be given the same authority as other department heads. That would relieve the governor greatly.

\section{SIGNING PAROLES}

The law requires that the governor sign all the parole sheets before men are liberated from the various prisons of the state, even after they have completed the minimum time for which they were sentenced. This is an absolutely useless proceeding. The governor can have no personal knowledge of it, and simply signs the sheets certified to him by the board of parole. 
They properly should be signed by the superintendent of prisons, he being in possession of all the records. They are brought before the governor, and without any knowledge of his own, and no opportunity of gaining any, he simply goes through the empty formality of signing them. They come with great frequency. Every time the board of parole meets, the lists are brought in. Not only must they be signed by the governor, but they must be attested by the secretary; thus the time of two busy men is taken up in a useless performance, which should be handled entirely by the superintendent of prisons.

In order that police officials appointed by railroad companies may have a state-wide power of arrest, some time ago the law was amended providing for their appointment by the governor. That means that large stacks of certificates of appointment of railroad policemen are laid before the governor for his signature. He does not know the men he appoints, and has to rely upon the railroad as to their integrity and honesty when having conferred upon them by the governor the power of arrest. If such appointments are necessary (which is probable) by some state power, it certainly ought not to be in the hands of the governor. I have spent whole hours at a time writing my name to appointments of railroad policemen. These men should be appointed by the attorney-general who has deputies to assist him in his work. Unfortunately there is no deputy governor.

\section{AN ARMY OF NOTARIES}

All applications for notaries publicand there are some 65,000 of them in the state-are sent to the executive chamber, making necessary a whole department in the governor's office for the handling of the applications. This function does not belong in the executive chamber. It should properly be either in the attorney-general's office or in the office of the secretary of state, where a large part of it might well be performed by deputies.

There is a provision of law which requires the governor to sign all contracts for repairs and betterments in the state hospitals-not only sign the contract, but also the architect's blueprints. He knows nothing about it and signs them usually upon the recommendation of the state architect. The law ought to be amended so that they be signed by the architect himself, and if there must be any check on the architect, it certainly should be by somebody in a position to know something about it, and not the governor.

\section{STATE CONSTABULARY}

The act creating the state constabulary contains a provision that the constabulary are not to exercise their powers in case of strike or riot within the boundaries of an incorporated city without the consent of the governor. This provision operated to make the governor the police commissioner when troops are needed for the suppression of riots inside of cities.

The result of this has been to cause the governor not only annoyance in the daytime, but at night. I was frequently called out of bed at night by the officials of small cities asking for the assistance of the state constabulary. In a great many instances their troubles were imaginary.

I have in mind one particular case where I was called up in the middle of the night by one official of the government of a city asking for the constabulary and called up an hour later by another official of the same city advising me not to send them in. That made 
necessary a conference in the nighttime with the superintendent of the state police and we satisfied everybody by sending the men there in citizen's clothes.

\section{LAST-MINUTE BILLS}

There is another important matter that deserves serious attention, that might be easily remedied. It would require only legislative action, either by amendment to the rules, or if not, by amendment of the legislative law, to prevent the dumping of a large number of bills into the executive chamber, giving the governor only thirty days to consider them.

At the last session of the legislature I had 856 thirty-day bills. That meant that I was given only thirty days to consider 856 bills. A great many of them were purely local in character; a great many of them were bills empowering the court of claims to hear and audit claims against the state.

This could be remedied by an amendment to the rules of the senate and assembly prohibiting the passage of purely local bills after a certain date in the session, so that the legislature may pass its unimportant local bills in the early months of the session, leaving the calendars clear at the end of the session for a discussion of the large proposals that affect all the people of the state.

This procedure would also give to the governor plenty of time and opportunity, in the thirty-day-bill period, to study out the larger proposals, and not have his time and the time of his office force taken up in passing on little local matters.

My experience at the close of the last session showed me that the large number of bills left with me could not be intelligently disposed of unless I worked from 9.30 in the morning until 1 or 2 o'clock the following morning. It is too much of a strain to put on the governor, and leaves him useless for some time after.

\section{OTHER SMALL DUTIES}

There are numerous other small detail duties that fall upon the governor in dealing with the great number of boards and commissions that we have transacting the state's business. The governor would be greatly relieved by the passage of the constitutional amendments reducing the large number of boards and commissions to eighteen departments of government, presided over by men given by law the necessary power to transact all the business of their departments.

The governor is unable to deny to citizens of the state serving on boards and commissions without salary, an opportunity to present to him their views about what is going on in their different institutions. Nothing takes more of the governor's time than listening to the complaints about the management of various institutions, large and small, all of which detail ought to be up to a man charged with that duty and with no other. It is because of that condition that I had to make a special trip to Bedford Reformatory, following the recent newspaper stories of riot and disorder at that institution.

The total net result of a New York governor's too-plentiful duties is that the great, big, prominent questions that affect the welfare of a commonwealth of over $10,000,000$ people are subordinated to the small, tiresome and irritating tasks that are put upon the governor by statute. 